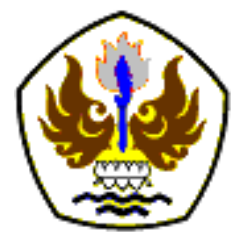

INFOMATEK

Volume 19 Nomor 2 Desember 2017

\title{
POTENSI PEMANFATAN SAMPAH DI PASAR LEUWILIANG, CIGUDEG DAN JASINGA KABUPATEN BOGOR MELALUI PENGOLAHAN SAMPAH TERPADU
}

\author{
Ratnaningsih ${ }^{*}$, Pramiati Purwaningrum, Fajriani Widya Haryanti \\ Jurusan Teknik Lingkungan \\ Fakultas Arsitektur Lansekap dan Teknologi Lingkungan - Universitas Trisakti
}

\begin{abstract}
Abstrak: Pasar traditional mempunyai kontribusi yang besar sebagai penghasil sampah, demikian juga Pasar Leuwiliang (luas $21.714 \mathrm{~m}^{2}$ ), Cigudeg (luas $11.000 \mathrm{~m}^{2}$ ) dan Jasinga (luas $18 \mathrm{~m}^{2}$ ) yang berada di Kabupaten Bogor. Tujuan dari penelitian ini adalah mengetahui potensi sampah untuk dimanfaatkan kembali dan merancang pengelolaan sampah terpadu sesuai dengan karakteristik dan komposisi sampahnya. Metode pengambilan sampel sampah berdasarkan SNI 19-3964-1994. Hasil penelitian diperoleh timbulan sampah Pasar Leuwiliang sebesar 46,36 $\mathrm{m}^{3} /$ hari, Pasar Cigudeg $57,73 \mathrm{~m}^{3} /$ hari dan Pasar Jasinga $120,65 \mathrm{~m}^{3} /$ hari. Laju timbulan sampah Pasar Leuwiliang sebesar 184,08 liter $/ \mathrm{m}^{2} /$ hari, Pasar Cigudeg sebesar $262,79 \mathrm{liter} / \mathrm{m}^{2} /$ hari dan Pasar Jasinga sebesar $311,118 \mathrm{liter} / \mathrm{m}^{2} /$ hari. Rata-rata komposisi sampah organik ketiga pasar tersebut sebesar $71 \%$ dan $29 \%$ non oganik. Perencanaan teknis pengelolaan sampah terdiri dari pemilahan, pewadahan, pengumpulan sampah, pengangkutan sampah dan pengolahan di Tempat Pengolahan Sampah Terpadu (TPST). Alat pengumpul direncanakan berupa gerobak dengan kapasitas $1 \mathrm{~m}^{3}$ sedangkan alat angkut direncanakan berupa dump truck dengan kapasitas $10 \mathrm{~m}^{3}$. Lokasi TPST direncanakan di Pasar Leuwiliang seluas $826 \mathrm{~m}^{2}$, dengan kapasitas $\pm 100 \mathrm{~m}^{3} /$ hari yang akan melayani sampah dari Pasar Leuwiliang, Pasar Cigudeg dan Pasar Jasinga. TPST tersebut direncanakan akan memiliki 6 bak pengomposan. Sampah organik yang akan diolah di TPST sekitar $70 \%$ dari total timbulan sampah sedangkan sisanya akan dipilah menjadi dua bagian yaitu sampah non organik yang akan dijual ke lapak dan residu akan diangkut ke TPA Galuga Bogor. Potensi sampah yang dapat dimanfaatkan kembali dari ketiga pasar tersebut mencapai $88,94 \%-99,44 \%$. Total kompos yang dihasilkan sebesar 1047,62 kg/hari dan total sampah non organik yang akan dijual ke pelapak sampah non organik adalah sebesar 708,95 kg/kg. Perencanaan TPST diharapkan dapat menjadi solusi dari masalah persampahan dan dapat memberi manfaat bagi masyarakat pasar maupun masyarakat sekitar pasar.
\end{abstract}

Kata kunci: Sampah, komposisi, pengelolaan sampah, TPST

\section{PENDAHULUAN}

Pengelolaan sampah saat ini harus diarahkan pada konsep 3R, sesuai Amanat UndangUndang No. 18 tahun 2008 tentang Pengelolaan Sampah, paradigma pengelolaan sampah harus dirubah dari kumpul-angkut-

\footnotetext{
*) ratnaningsih@trisakti.ac.id
}

buang menjadi pengurangan di sumber dan daur ulang sumberdaya. Pendekatan end of pipe diganti dengan prinsip 3R (reduce, reuse, recycle)(Dinas Kebersihan dan Pertamanan [1]). Hal ini bertujuan agar sampah dapat ditangani dengan baik, kebutuhan akan lahan untuk landfill dapat berkurang, dan mengurangi biaya pengelolaan sampah. 
Di negara berkembang, pasar tradisional umumnya memiliki kontribusi cukup besar sebagai penghasil sampah (Matsui dkk. [2]). Demikian juga di wilayah kabupaten Bogor, pada tahun 2012 total timbulan sampah pasar mencapai sekitar $50 \%$ dari sampah yang dihasilkan di Kabupaten Bogor (7400 $\mathrm{m}^{3} /$ tahun, sedangkan sampah yang bersumber dari 25 pasar mencapai 3700 $\mathrm{m}^{3} /$ tahun [1]. Dari 25 pasar di wilayah Kabupaten Bogor, hanya 2 pasar (pasar Ciomas dan Pasar Citeuruep) saja yang telah melakukan pengolahan sampah pasar, sedang yang lainnya dibuang ke TPA Galuga.

Beberapa hasil penelitian menunjukkan bahwa sampah pasar memiliki potensi untuk didaur ulang baik sebagai pupuk organik maupun sebagai pakan ternak. Matsui [2] melaporkan bahwa sampah pasar memiliki potensi lebih dari $82.3 \%$ dapat dibuat kompos atau makanan ternak. Sedangkan Hartono dkk. menyatakan bahwa berdasarkan hasil penelitian terhadap komposisi sampah di Pasar Pondok Bambu dan Pasar Cinere, menunjukkan bahwa lebih dari $40 \%$ sampah dapat didaur ulang, sehingga dapat mengurangi beban landfill (Hartono dkk, [3]).

Penelitian dilakukan di tiga pasar yaitu Pasar Leuwiliang, Cigudeg dan Jasinga. Pasar Leuwiliang, Cigudeg, Jasinga memiliki kios sebanyak 462 unit, 361 unit, 713 unit dan los sebanyak 195 unit, 128 unit, 156, selain itu pasar Jasinga memiliki ruko sebanyak 6 unit. Ketiga pasar tersebut menghasilkan rata-rata timbulan sampah sebesar $12 \mathrm{~m}^{3} /$ hari, yang didominasi oleh sampah organik.

Penelitian bertujuan untuk melihat potensi pengelolaan sampah di ketiga pasar tersebut dalam satu lokasi dengan menerapkan konsep 3R, dirancang menjadi Tempat Pengolahan Sampah Terpadu. Tempat pengolahan sampah terpadu atau TPST adalah tempat dilaksanakannya pengumpulan, pemilahan, penggunaan ulang, pendaur ulangan, dan pemrosesan akhir sampah. (Undang-Undang No 18 Tahun 2008 [4]). Tempat pengolahan sampah terpadu atau TPST adalah suatu tempat yang memiliki berbagai macam kegiatan yang bertujuan untuk mengurangi timbulan sampah. Kegiatan-kegiatan tersebut terdiri dari pengelolaan sampah, baik organik maupun non organik [4].

\section{METODE PENELITIAN}

\subsection{Waktu dan Tempat}

Penelitian dilakukan pada bulan Agustus hingga Desember 2016, yang dilaksanakan di tiga pasar yang berada di wilayah Kabupaten Bogor yaitu Pasar Leuwiliang (Jl. Raya Leuwiliang, Kecamatan Leuwiliang); Pasar Cigudeg (Jl. Raya Cigudeg, Kecamatan Cigudeg) dan Pasar Jasinga (Jl. Raya Jasinga, Kecamatan Jasinga). Pengambilan 
sampel dilakukan di tiga pasar tersebut selama 8 hari berturut-turut.

\subsection{Metoda Pengambilan Sampel}

Tahapan penelitian terdiri dari pengambilan data sekunder, pengambilan data primer yang dilakukan dengan cara pengambilan sampel dan penyebaran kuesioner, evaluasi kondisi pengelolaan sampah di ketiga Pasar tersebut dan kemudian melakukan analisa potensi pemanfaatan kembali sampah yang dihasilkan, dan menyusun rancangan sistem pengelolaan sampah untuk ketiga pasar tersebut. Sampling dilakukan dengan menggunakan metode SNI 19-3964-1994, sedangkan penentuan jumlah sampel kuesioner menggunakan Rumus Slovin.

\subsection{Analisis Data}

Analisis data dilakukan dengan cara mengevaluasi pengelolaan sampah Pasar Leuwiliang, Pasar Cigudeg dan Pasar Jasinga yang meliputi 657 pedagang Pasar Leuwiliang, 489 pedagang Pasar Cigudeg dan 875 pedagang Pasar Jasinga dengan luas Pasar Leuwiliang $21.714 \mathrm{~m}^{2}$, Pasar Cigudeg seluas $11.000 \mathrm{~m}^{2}$ dan Pasar Jasinga seluas $18.000 \mathrm{~m}^{2}$.

Selain mengevaluasi pengelolaan sampah pasar, dilakukan juga analisis karakteristik dan timbulan sampah yang dihasilkan oleh ketiga pasar tersebut dengan terlebih dahulu mengetahui pola pengelolaan sampah pasar mulai dari pewadahan sampah hingga sampah diangkut menuju ke Tempat Pemrosesan Akhir (TPA).

Setelah itu melakukan penghitungan potensi sampah yang dapat dimanfaatkan kembali, dan dilanjutkan dengan perencanaan pengelolaan sampah organik dan sampah non organik di ketiga pasar tersebut secara terpadu. Beberapa perhitungan yang digunakan antara lain adalah :

\section{Rumus Laju Timbulan Sampah}

- Laju Timbulan Sampah

$$
=\frac{\text { Total berat sampel sampah }}{\text { jumlah sampel los/kios/toko }}
$$

- Volume Timbulan Sampah $=$ Laju timbulan sampah (liter $/ \mathrm{m}^{2} /$ hari) $\times$ jumlah keseluruhan los/kios/ruko

- Densitas Sampah

$$
=\frac{\text { Berat timbulan sampah }}{\text { Volume timbulan sampah }}
$$

\section{Rumus Proyeksi Laju Timbulan Sampah}

$$
Q_{t}=Q_{0} \times\left(1+C_{s}\right)^{n}
$$

Keterangan :

$$
\begin{aligned}
Q_{\mathrm{t}}(\mathrm{n})= & \text { Laju timbulan sampah pada } \mathrm{n} \\
& \text { tahun mendatang }\left(\mathrm{m}^{3} / \mathrm{hari}\right) \\
\mathrm{Q}_{0} \quad= & \text { Laju timbulan sampah } \\
& \text { eksisting (0 tahun) } \\
\mathrm{n} \quad= & \text { Banyaknya tahun } \\
\mathrm{C}_{\mathrm{s}} \quad= & \text { Peningkatan sampah per } \\
& \text { tahun }
\end{aligned}
$$




\section{HASIL DAN PEMBAHASAN}

\subsection{Timbulan Sampah Pasar Leuwiliang, Cigudeg dan Jasinga}

Pasar Leuwiliang

Pada Pasar Leuwiliang, timbulan sampah los terbesar berasal dari los sayuran. Timbulan sampah los yang terkecil berasal dari los makanan-minuman dan los snack/ makanan ringan seperti pada Gambar 1. Sedangkan untuk kios seperti pada Gambar 2, timbulan sampah terbesar berasal dari kios bumbu dan kios makanan-minuman. Timbulan sampah kios yang terkecil berasal dari kios snack/ makanan ringan dan kios kerudung.
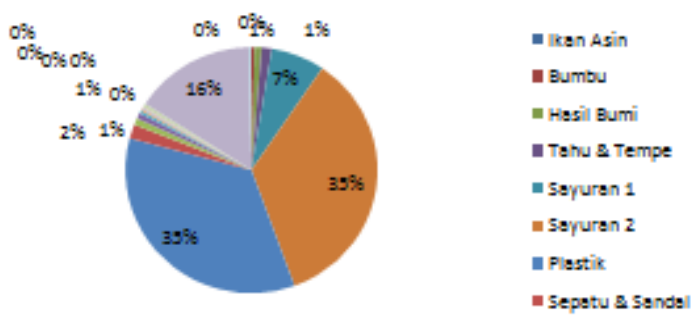

Gambar 1

Timbulan Sampah Los Pasar Leuwiliang.
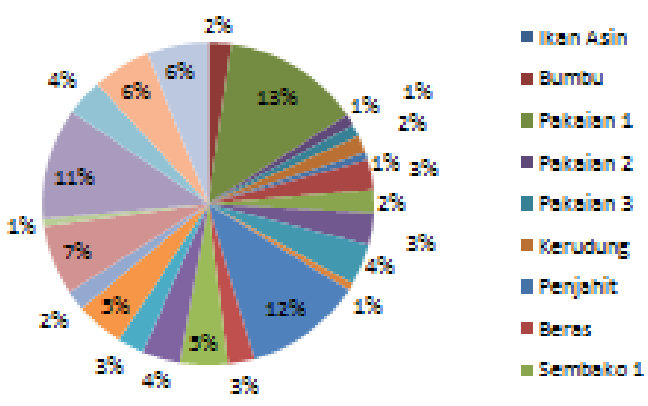

Gambar 2

Timbulan Sampah Kios Pasar Leuwiliang.
Berdasarkan hasil penelitian total timbulan sampah Pasar Leuwiliang sebesar 25,9 $\mathrm{m}^{3} /$ hari.

\section{Pasar Cigudeg}

Sedangkan untuk pasar Cigudeg, timbulan sampah los terbesar berasal dari los sayuran dan los buah timbulan sampah los yang terkecil berasal dari los ikan mas dan los ayam potong seperti terlihat pada Gambar 3. Dan timbulan sampah kios yang terbesar berasal dari kios buah, timbulan sampah kios yang terkecil berasal dari kios pakaian dan kios kitab seperti terlihat pada Gambar 4.
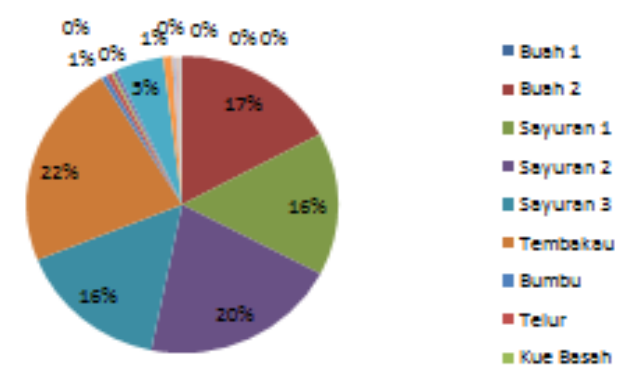

Gambar 3

Timbulan Sampah Los Pasar Cigudeg.

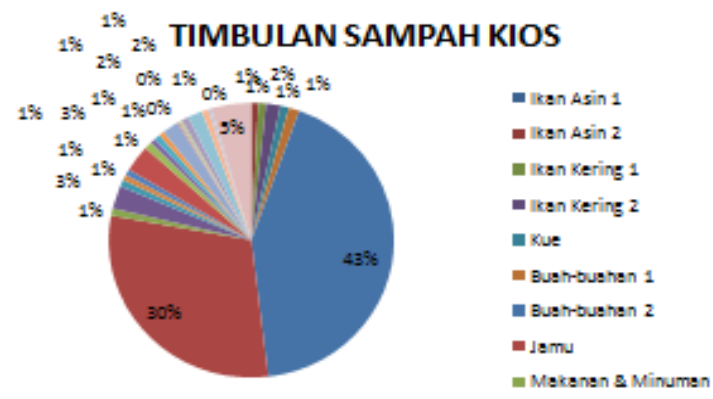

Gambar 4. Timbulan Sampah Kios Pasar Cigudeg. 
Potensi Pemanfatan Sampah di Pasar Leuwiliang, Cigudeg dan Jasinga Kabupaten Bogor melalui Pengolahan Sampah Terpadu

Berdasarkan hasil penelitian bahwa total timbulan sampah Pasar Cigudeg sebesar $39,81 \mathrm{~m}^{3} /$ hari.

\section{Pasar Jasinga}

Timbulan sampah kios Pasar Jasinga, yang terbesar berasal dari kios buah, kios sayuran dan untuk timbulan sampah kios yang terkecil berasal dari kios warung nasi/kopi dan kios ikan kering seperti terlihat pada Gambar 5.

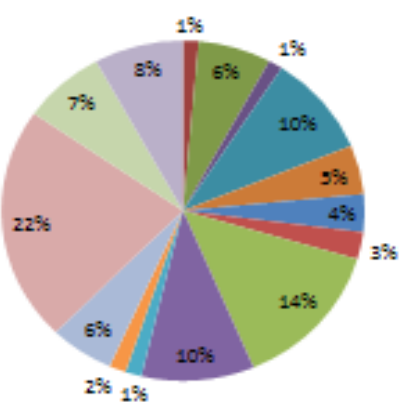

Gambar 5

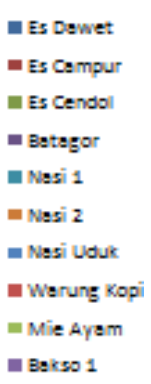

Bakso 1
Timbulan Sampah Los Pasar Jasinga.

Timbulan sampah los terbesar berasal dari los soto, los warung kopi dan los batagor sedangkan timbulan sampah los yang terkecil berasal dari los es cendol, los es dawet dan los nasi uduk seperti pada Gambar 6.

Sedangkan, timbulan sampah ruko terbesar berasal dari ruko mini market. untuk timbulan sampah ruko yang terkecil berasal dari ruko emas seperti terlihat pada Gambar 7.

Berdasarkan hasil penelitian menunjukkan bahwa timbulan sampah sebesar 57,68 $\mathrm{m}^{3} /$ hari.
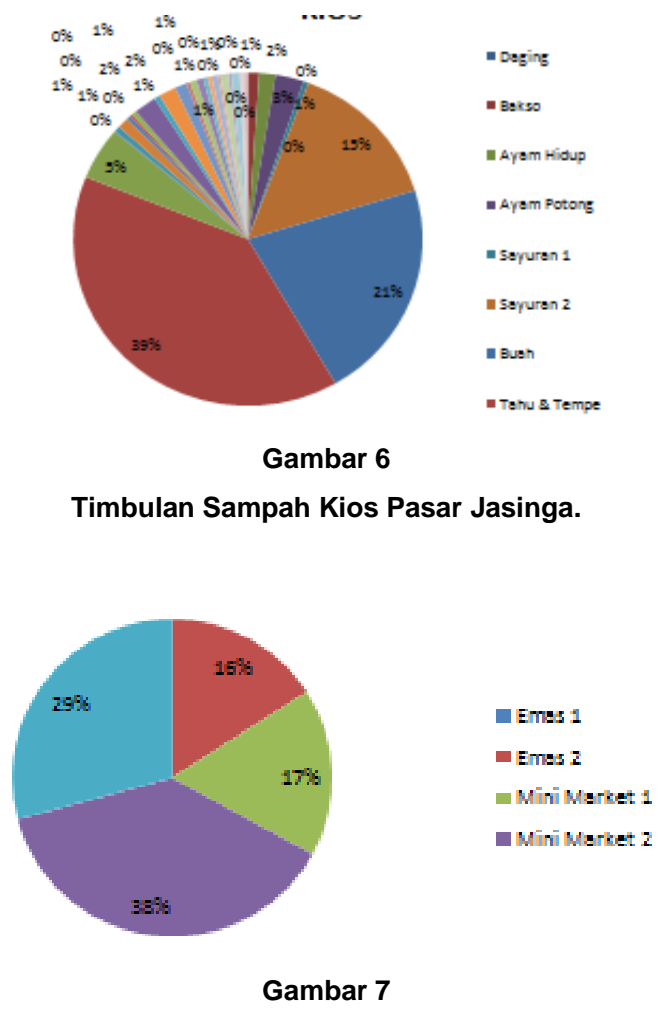

Timbulan Sampah Ruko Pasar Jasinga

Hal tersebut menunjukkan bahwa masih banyak sampah dari ketiga pasar tersebut yang belum tertangani yaitu sekitar $80 \%$ oleh pihak pengelola pasar serta tidak terangkut oleh pihak Dinas Kebersihan dan Pertamanan Kabupaten Bogor.

\subsection{Komposisi Sampah}

Di dalam merencanakan pengolahan sampah pasar dibutuhkan penelitian mengenai komposisi sampah ketiga pasar tersebut. Berdasarkan hasil penelitian komposisi sampah maka dapat ditentukan pengolahan sampah pasar yang sesuai dengan potensi 
sampah yang dapat didaur ulang maupun yang tidak dapat didaur ulang.

\section{Komposisi Sampah Pasar Leuwiliang}

Berdasarkan hasil penelitian menunjukkan bahwa komposisi sampah organik yang dapat didaur ulang sebesar 68\% dan komposisi sampah organik yang tidak dapat didaur ulang sebesar 3\%, sedangkan untuk komposisi sampah non organik yang dapat dijual sebesar $15 \%$ dan yang tidak dapat dijual sebesar $14 \%$ seperti terlihat pada Gambar 8 .

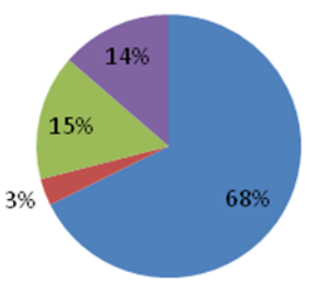

Gambar 8

\section{Komposisi Sampah Pasar Cigudeg}

Hasil penelitian menunjukkan bahwa prosentase komposisi sampah organik yang dapat didaur ulang sebesar $64 \%$ dan komposisi sampah organik yang tidak dapat didaur ulang sebesar $8 \%$, sedangkan untuk komposisi sampah non organik yang dapat dijual sebesar $14 \%$ dan yang tidak dapat dijual sebesar 14\% seperti terlihat pada Gambar 9.

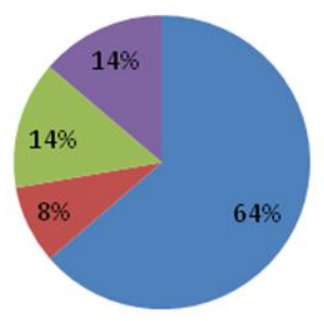

- Organik yang dapat didaur ulang

- Organik yang tidak dapat didaur ulang

Non Organik yang dapat dijual

Non Organik yang tidak dapat dijual

\section{Gambar 9}

Komposisi Sampah Pasar Cigudeg.

\section{Komposisi Sampah Pasar Jasinga}

Berdasarkan hasil penelitian menunjukkan bahwa prosentase komposisi sampah organik yang dapat didaur ulang sebesar 64\% dan komposisi sampah organik yang tidak dapat didaur ulang sebesar 5\%, sedangkan untuk komposisi sampah non organik yang dapat dijual sebesar $11 \%$ dan yang tidak dapat dijual sebesar 20\% seperti terlihat pada Gambar 10. Sampah organik yang tidak dapat didaur ulang dan sampah non organik yang tidak dapat dijual merupakan residu yang akan diangkut menuju TPA Galuga Bogor.

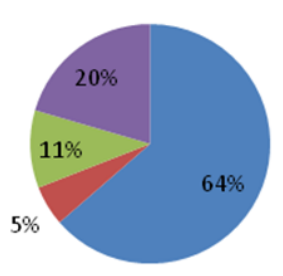

$$
\begin{aligned}
& \text { Organik yang dapat } \\
& \text { didaur ulang } \\
& \text { Organik yang tidak dapat } \\
& \text { didaur ulang } \\
& \text { Non Organik yang dapat } \\
& \text { dijual } \\
& \text { Non Organik yang tidak } \\
& \text { dapat dijual }
\end{aligned}
$$

Gambar 10

Komposisi Sampah Pasar Jasinga.

Berdasarkan hasil penelitian komposisi sampah pada ketiga pasar tersebut maka diperoleh rata-rata sampah organik yang dapat didaur ulang adalah sebesar 65\%. 
Potensi Pemanfatan Sampah di Pasar Leuwiliang, Cigudeg dan Jasinga Kabupaten Bogor melalui Pengolahan Sampah Terpadu

Dengan komposisi tersebut maka dapat dilakukan daur ulang sampah organik yaitu salah satunya dengan melakukan pengomposan sampah pasar. Pengolahan sampah untuk ketiga pasar tersebut dapat dilakukan di Tempat Pengolahan Sampah Terpadu (TPST).

\subsection{Proyeksi Timbulan Sampah}

Didalam merencanakan pengelolaan sampah dalam 20 tahun perencanaan dibutuhkan proyeksi timbulan sampah masing-masing pasar. Proyeksi timbulan sampah ketiga pasar tersbut berdasarkan peruntukan masingmasing yaitu los, kios dan ruko seperti terlihat pada Gambar 11 hingga Gambar 17.

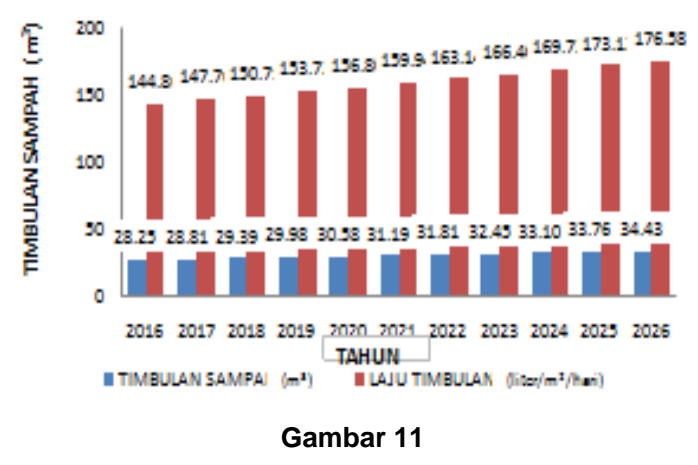

Proyeksi Timbulan Sampah Los Pasar Leuwiliang.

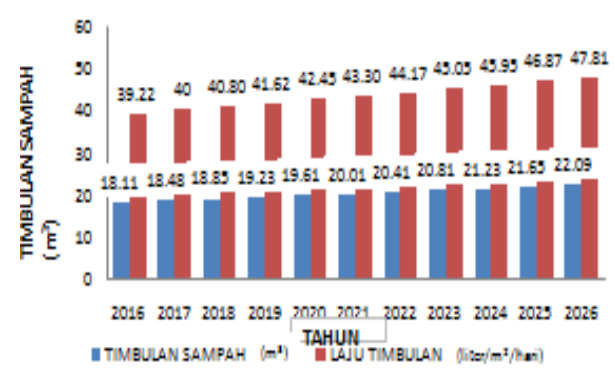

Gambar 12

Proyeksi Timbulan Sampah Kios Pasar Leuwiliang.

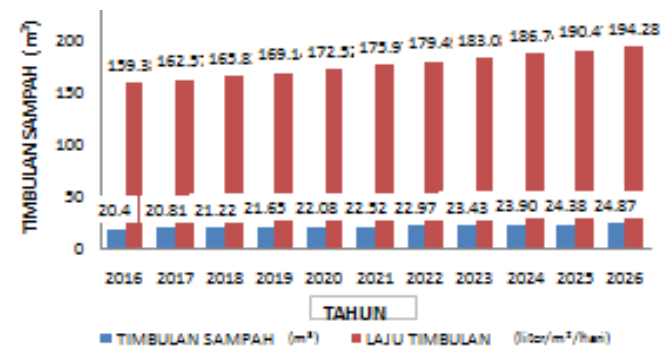

Gambar 13

Proyeksi Timbulan Sampah Los Pasar Cigudeg.

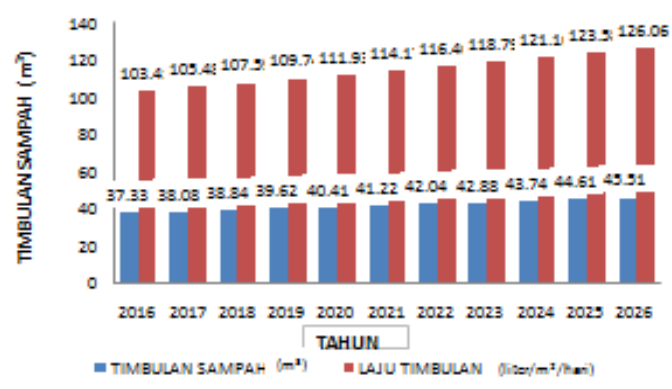

Gambar 14

Proyeksi Timbulan Sampah Kios Pasar Cigudeg.

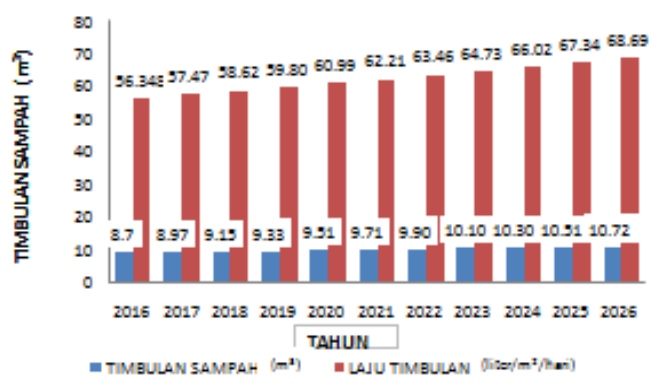

Gambar 15

Proyeksi Timbulan Sampah Los Pasar Jasinga.

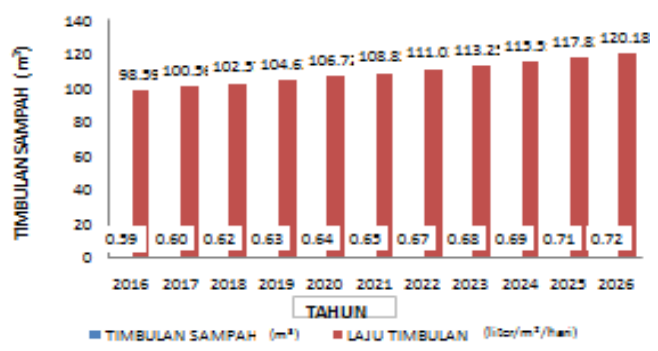

Gambar 16

Proyeksi Timbulan Sampah Ruko Pasar Jasinga. 


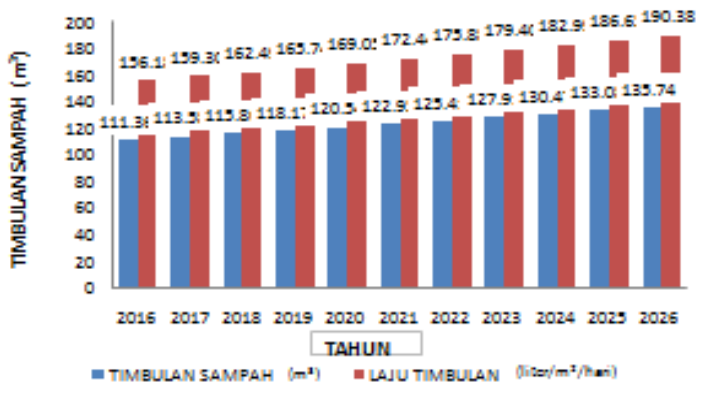

Gambar 17

Proyeksi Timbulan Sampah Kios Pasar Jasinga.

Menurut data pihak pasar yaitu PD. Pasar Tohaga Kabupaten Bogor, volume sampah di ketiga pasar yaitu Pasar Leuwiliang, Pasar Cigudeg dan Pasar Jasinga meningkat sebesar $2 \%$ per tahun. Peningkatan timbulan sampah sebesar $2 \% / t a h u n$ disebabkan jumlah konsumen pada Pasar Leuwiliang, Cigudeg dan Jasinga bertambah setiap tahunnya sehingga jumlah yang dijual bertambah dan tentunya akan menghasilkan sampah yang bertambah banyak setiap tahunnya. Kapasitas maksimal daya tampung pasar terhadap sampah yang dihasilkan sebesar $2 \% /$ tahun.

Berdasarkan hasil penelitian diperoleh laju timbulan sampah di Pasar Leuwiliang pada los sebesar 144,86 liter $/ \mathrm{m}^{2} /$ hari dan pada kios sebesar 39,22 liter $/ \mathrm{m}^{2} /$ hari. di Pasar Cigudeg pada los sebesar $159.38 \mathrm{liter} / \mathrm{m}^{2} /$ hari, pada kios sebesar 103,41 liter $/ \mathrm{m}^{2} /$ hari. di Pasar Jasinga pada los sebesar 56,35 liter $/ \mathrm{m}^{2} /$ hari, kios 156,18 liter $/ \mathrm{m}^{2} /$ hari dan ruko sebesar $98,59 \mathrm{liter} / \mathrm{m}^{2} /$ hari.

Sedangkan untuk timbulan sampah di Pasar Leuwiliang pada los sebesar 28,25 $\mathrm{m}^{3} /$ hari dan pada kios sebesar $18,11 \mathrm{~m}^{3} /$ hari. Untuk di pasar Cigudeg pada los sebesar 20,4 $\mathrm{m}^{3}$ /hari dan pada kios sebesar $37,33 \mathrm{~m}^{3} /$ hari. Untuk Pasar Jasinga pada los sebesar $8,7 \mathrm{~m}^{3} /$ hari, pada kios sebesar $111,36 \mathrm{~m}^{3} /$ hari dan pada ruko sebesar $0,59 \mathrm{~m}^{3} /$ hari.

Untuk merencanakan pengelolaan sampah pasar ketiga pasar tersebut maka diperlukan data sarana prasarana masing-masing pasar. Sarana dan prasarana yang dimiliki oleh ketiga pasar seperti terlihat pada Tabel 1.

Tabel 1

Rekapitulasi Sarana Prasarana yang dimiliki oleh Ketiga Pasar

\begin{tabular}{|c|c|c|c|}
\hline $\begin{array}{l}\text { LOKASI } \\
\text { PASAR }\end{array}$ & $\begin{array}{c}\text { JENIS SARANA } \\
\text { PRASARANA }\end{array}$ & JML & KAPASITAS \\
\hline $\begin{array}{c}\text { PASAR } \\
\text { LEUWILIANG }\end{array}$ & $\begin{array}{l}\text { 1.Tong Sampah } \\
\text { Plastik } \\
\text { 2. TPS } \\
\text { 3. Gerobak } \\
\text { 4. Truk biasa } \\
\text { 5. Sapu lidi } \\
\text { 6. Masker } \\
\text { 7. Sepatu Boat } \\
\text { 8. Serokan } \\
\text { 9.Sarung } \\
\quad \text { tangan }\end{array}$ & $\begin{array}{c}10 \\
1 \\
1 \\
1 \\
2 \\
16 \\
16 \\
2 \\
16\end{array}$ & $\begin{array}{c}20 \text { liter } \\
\text { ukuran } 25 \mathrm{~m}^{2} \\
1 \mathrm{~m}^{3} \\
10 \mathrm{~m}^{3} \\
- \\
- \\
- \\
- \\
-\end{array}$ \\
\hline $\begin{array}{l}\text { PASAR } \\
\text { CIGUDEG }\end{array}$ & $\begin{array}{l}\text { 1. Tong Sampah } \\
\text { Plastik } \\
\text { 2. TPS } \\
\text { 3. Gerobak } \\
\text { 4. Truk biasa } \\
\text { 5. Sapu lidi } \\
\text { 6. Masker } \\
\text { 7. Sepatu Boat } \\
\text { 8. Serokan } \\
\text { 9.Sarung } \\
\quad \text { tangan }\end{array}$ & $\begin{array}{c}10 \\
1 \\
1 \\
1 \\
2 \\
13 \\
13 \\
2 \\
13\end{array}$ & $\begin{array}{c}20 \text { liter } \\
\text { ukuran } 9 \mathrm{~m}^{2} \\
1 \mathrm{~m}^{3} \\
10 \mathrm{~m}^{3} \\
- \\
- \\
- \\
- \\
-\end{array}$ \\
\hline $\begin{array}{l}\text { PASAR } \\
\text { JASINGA }\end{array}$ & $\begin{array}{l}\text { 1. Tong Sampah } \\
\text { Plastik } \\
\text { 2. TPS } \\
\text { 3. Gerobak } \\
\text { 4. Truk biasa } \\
\text { 5. Sapu lidi } \\
\text { 6. Masker } \\
\text { 7. Sepatu Boat } \\
\text { 8. Serokan } \\
\text { 9.Sarung } \\
\quad \text { tangan }\end{array}$ & $\begin{array}{c}9 \\
1 \\
1 \\
1 \\
2 \\
17 \\
17 \\
2 \\
17\end{array}$ & $\begin{array}{c}20 \text { liter } \\
\text { ukuran } 10 \mathrm{~m}^{2} \\
1 \mathrm{~m}^{3} \\
10 \mathrm{~m}^{3} \\
- \\
- \\
- \\
- \\
-\end{array}$ \\
\hline
\end{tabular}




\subsection{Peran Serta Masyarakat Pasar} Terhadap Pengelolaan Sampah Terpadu di Pasar Leuwiliang

Untuk mengetahui peran serta masyarakat pasar terhadap pengelolaan sampah terpadu maka dilakukan wawancara dengan membagikan kuesioner kepada 178 responden di Pasar Leuwiliang, 164 responden di Pasar Cigudeg dan 200 responden di Pasar Jasinga.

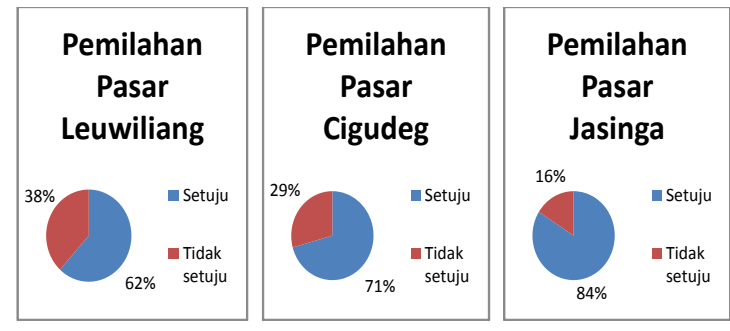

Gambar 18

Kesediaan Masyarakat Pasar Leuwiliang, Cigudeg dan Jasinga untuk Melakukan Pemilahan Sampah di sumber.

Berdasarkan hasil kuesioner menunjukan bahwa responden yang memiliki respons positif, bersedia melalukan pemilahan pada Pasar Leuwiliang 62\%, Cigudeg sebanyak $71 \%$ dan Jasinga sebanyak $84 \%$ sedang sisanya memberi respons negatif, yaitu tidak bersedia melakukan pemilahan sampah seperti terlihat pada Gambar 18.

Masyarakat pasar bersedia melakukan pemilahan sampah, jika pihak pengelola pasar menyediakan tempat sampah yang terpisah antara organik dengan non organik, sedangkan masyarakat pasar yang tidak bersedia melakukan pemilahan sampah beralasan bahwa mereka tidak memiliki waktu untuk melakukan pemilahan, sehingga mereka lebih memilih untuk mengandalkan petugas kebersihan baik dari Dinas Kebersihan maupun dari pihak pengelola pasar.

\subsection{Perencanaan Pengelolaan Sampah Terpadu di Pasar Leuwiliang Kabupaten Bogor}

Perencanaan pengelolaan sampah meliputi kegiatan pewadahan, pengumpulan, pemilahan, pengangkutan sampah dari Pasar Jasinga dan Pasar Cigudeg menuju Tempat Pengolahan Sampah Terpadu (TPST) Pasar Leuwiliang, pengelolaan sampah di TPST Pasar Leuwiliang dan pengangkutan sampah dari Pasar Leuwiliang menuju Tempat Pemrosesan Akhir Galuga Bogor (TPA).

Perencanaan TPST Pasar Leuwiliang akan dilakukan berdasarkan kondisi pasar serta mempertimbangkan potensi pemanfaatan kembali sampah yang ditinjau dari beberapa aspek yaitu aspek lingkungan, aspek ekonomi dan aspek sosial. Pengelolaan sampah yang akan dilakukan di Pasar Leuwiliang terdiri dari pengomposan sampah organik dan penjualan sampah non organik. Berdasarkan beberapa pertimbangan seperti biaya operasional, waktu pengomposan serta kualitas kompos, maka 
metode pengomposan yang terpilih adalah metode Bokashi.

Perencanaan pengelolaan sampah terdiri dari pewadahan, pengumpulan dan pengangkutan. Pemilihan alternatif dilakukan dengan melihat aspek biaya, operasional, lingkungan, jarak dan waktu tempuh. Bila alternatif memenuhi kelima aspek, maka alternatif tersebut dapat dipilih untuk perencanaan pengelolaan sampah. Pada pewadahan tedapat tiga alternatif seperti pada Tabel 2 dan 3 serta pada pengangkutan terdapat tiga alternatif. Namun pada pengumpulan setiap alternatifnya sama-sama menggunakan gerobak berkapasitas $1 \mathrm{~m}^{3}$.

\section{Tabel 2}

Perbedaan dari ketiga alternatif

\begin{tabular}{|c|c|c|c|}
\hline & \multicolumn{3}{|c|}{ ALTERNATIF } \\
\hline & 1 & 2 & 3 \\
\hline $\begin{array}{l}\text { 1. Pewa- } \\
\text { dahan }\end{array}$ & $\begin{array}{l}\text { Los : } \\
\text { Tong/drum } \\
\text { sampah plastik } \\
\text { berkapasitas } \\
50 \text { liter } \\
\text { Kios : } \\
\text { Tong/drum } \\
\text { sampah plastik } \\
\text { berkapasitas } \\
150 \text { liter } \\
\text { Ruko : } \\
\text { Tong/drum } \\
\text { sampah plastik } \\
\text { berkapasitas } \\
150 \text { liter }\end{array}$ & $\begin{array}{l}\text { Los: } \\
\text { Polybag } \\
\text { berkapasitas } \\
100 \text { liter } \\
\text { Kios : } \\
\text { Polybag } \\
\text { berkapasitas } \\
100 \text { liter } \\
\\
\text { Ruko : } \\
\text { Polybag } \\
\text { berkapasitas } \\
100 \text { liter }\end{array}$ & $\begin{array}{l}\text { Los: } \\
\text { Polybag } \\
\text { berkapasitas } \\
100 \text { liter } \\
\text { Kios: } \\
\text { Polybag } \\
\text { berkapasitas } \\
100 \text { liter } \\
\\
\text { Ruko : } \\
\text { Tong/drum } \\
\text { sampah } \\
\text { plastik } \\
\text { berkapasitas } \\
150 \text { liter }\end{array}$ \\
\hline $\begin{array}{l}2 . \\
\text { Pengum- } \\
\text { pulan }\end{array}$ & $\begin{array}{l}\text { Gerobak } \\
\text { berkapasitas } 1 \\
\mathrm{~m}^{3}\end{array}$ & $\begin{array}{l}\text { Gerobak } \\
\text { berkapasitas } 1 \\
\mathrm{~m}^{3}\end{array}$ & $\begin{array}{l}\text { Gerobak } \\
\text { berkapasitas } 1 \\
\mathrm{~m}^{3}\end{array}$ \\
\hline $\begin{array}{l}\text { 3. Peng- } \\
\text { angkut- } \\
\text { an }\end{array}$ & $\begin{array}{l}\text { - Dump Truck } \\
\text { berkapasitas } \\
10 \mathrm{~m}^{3} \\
\text { - Memiliki } 2 \\
\text { Jenis } \\
\text { Pengangkutan }\end{array}$ & $\begin{array}{l}\text { - Dump Truck } \\
\text { berkapasitas } 10 \\
\mathrm{~m}^{3} \\
\text { - Memiliki } 3 \\
\text { Jenis } \\
\text { Pengangkutan }\end{array}$ & - \\
\hline
\end{tabular}

Tabel 3

Rekapitulasi Kebutuhan Pewadahan, Gerobak dan Truk

\begin{tabular}{|c|c|c|c|}
\hline $\begin{array}{l}\text { LOKASI } \\
\text { PASAR }\end{array}$ & $\begin{array}{c}\text { KEBUTUHAN } \\
\text { PEWADAHAN } \\
(2026)\end{array}$ & $\begin{array}{l}\text { KEBUTUHAN } \\
\text { GEROBAK } \\
(2026)\end{array}$ & $\begin{array}{c}\text { KEBUTUHAN } \\
\text { TRUK } \\
(2026)\end{array}$ \\
\hline $\begin{array}{c}\text { PASAR } \\
\text { LEUWILIA } \\
\text { NG }\end{array}$ & $\begin{array}{l}\text { Los }=195 \text { unit } \\
\text { Polybag } \\
\text { Kios }=231 \text { unit } \\
\text { Polybag }\end{array}$ & $\begin{array}{l}\text { Los }=8 \text { unit } \\
\text { Kios }=6 \text { unit }\end{array}$ & truk $=0$ unit \\
\hline $\begin{array}{c}\text { PASAR } \\
\text { CIGUDEG }\end{array}$ & $\begin{array}{l}\text { Los }=128 \text { unit } \\
\text { Polybag } \\
\text { Kios }=361 \text { unit } \\
\text { Polybag }\end{array}$ & $\begin{array}{l}\text { Los }=7 \text { unit } \\
\text { Kios }=12 \text { unit }\end{array}$ & truk = 4 unit \\
\hline $\begin{array}{c}\text { PASAR } \\
\text { JASINGA }\end{array}$ & $\begin{array}{l}\text { Los }=156 \text { unit } \\
\text { Kios }=713 \text { unit } \\
\text { Ruko }=6 \text { unit }\end{array}$ & $\begin{array}{l}\text { Los }=3 \text { unit } \\
\text { Kios }=34 \text { unit } \\
\text { Ruko }=1 \text { unit }\end{array}$ & truk $=7$ unit \\
\hline
\end{tabular}

\subsection{Rancangan Tempat Pengolahan Sampah Terpadu di Pasar Leuwiliang}

Pihak yang akan ikut berpastisipasi dalam perencanaan ini adalah para pedagang, pihak pengelola pasar dan pihak Dinas Kebersihan \& Pertamanan Kabupaten Bogor. Luas lahan yang akan digunakan $2157,88 \mathrm{~m}^{2}$ dan luas TPST Pasar Leuwiliang yaitu sekitar 2109,25 $\mathrm{m}^{2}$ dengan kapasitas sebesar $1386 \mathrm{~m}^{3}$. Luas TPST Pasar Leuwiliang terdiri dari :

1. Ruang kantor seluas $14 \mathrm{~m} \times 6 \mathrm{~m}$ yang termasuk di dalamnya terdapat 2 kamar mandi dengan luas $2,5 \mathrm{~m} \times 1,5 \mathrm{~m}$

2. Ruang penerimaan dan pemilahan sampah seluas $14 \mathrm{~m} \times 4 \mathrm{~m}$

3. Ruang tempat pemilahan sampah non organik seluas $7 \mathrm{~m} \times 4 \mathrm{~m}$

4. Ruang tempat residu sampah seluas $7 m \times 4 m$

5. Ruang tempat penyimpanan sampah non organik yang akan dijual seluas $7 \mathrm{~m} \times 4 \mathrm{~m}$ 
Potensi Pemanfatan Sampah di Pasar Leuwiliang, Cigudeg dan Jasinga Kabupaten Bogor melalui Pengolahan Sampah Terpadu

6. Ruang tempat pencacahan kompos dan pemilahan sampah organik seluas $7 \mathrm{~m} \times 4 \mathrm{~m}$

7. Ruang gudang hasil produksi kompos seluas $7 \mathrm{~m} \times 4 \mathrm{~m}$

8. Ruang gudang peralatan seluas $7 \mathrm{~m} \times 4 \mathrm{~m}$
9. Tempat/ batch pengomposan dengan masing-masing ukuran seluas $14 \mathrm{~m} \times 13,5 \mathrm{~m}$

10.Ruang tempat pengayakan kompos seluas $14 \mathrm{~m} \times 13,5 \mathrm{~m}$

11. Halaman depan TPST seluas $29,5 m \times 2 m$

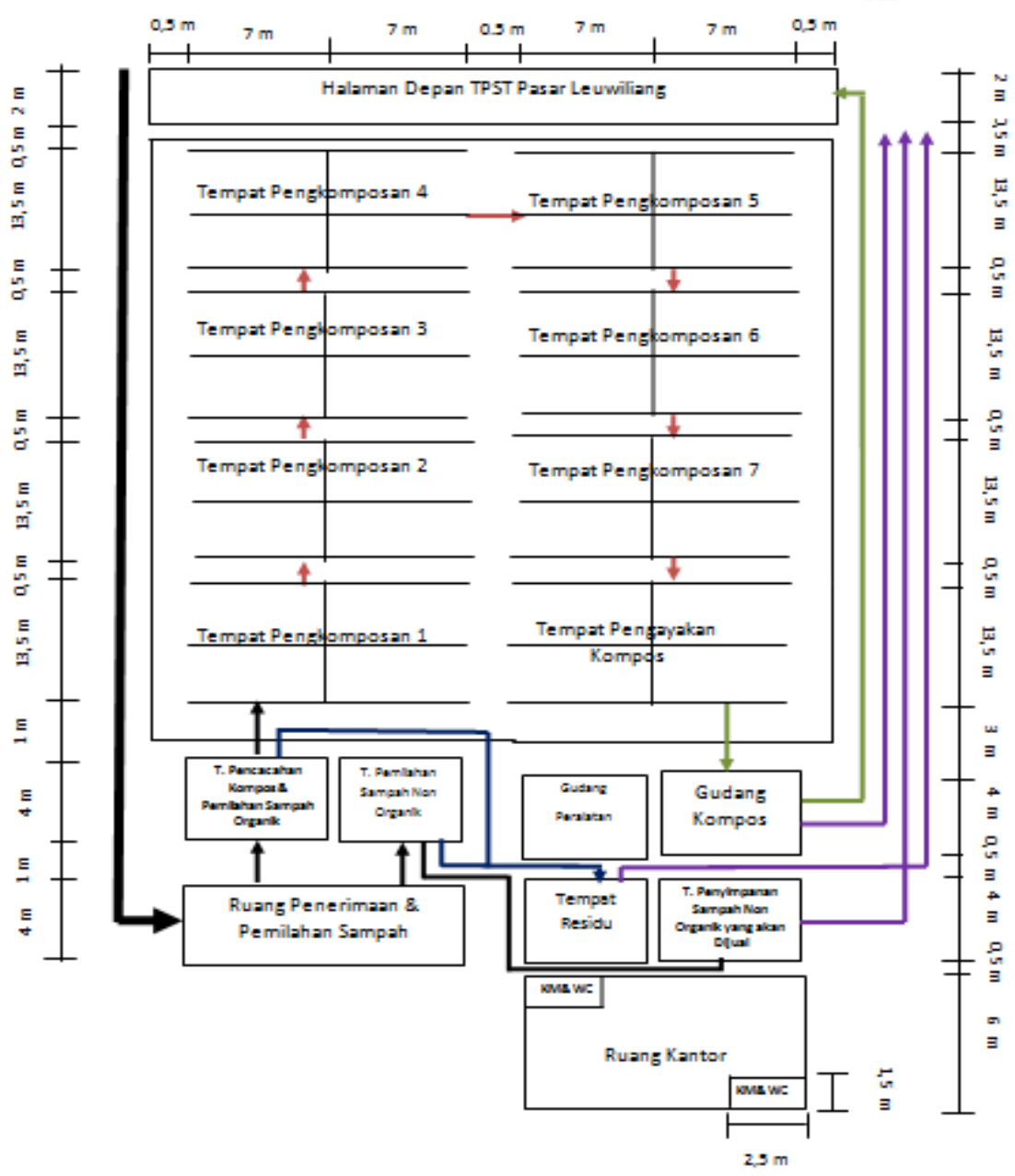

Keterangan

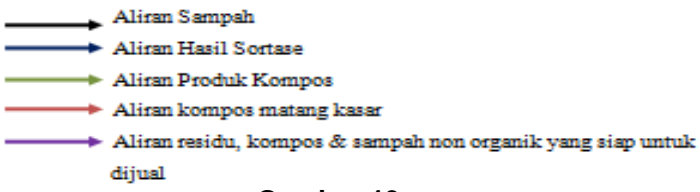

Gambar 19

Rencana Layout TPST Pasar Leuwiliang 
Dari hasil penelitian dan perhitungan, sampah yang akan dikelola di TPST pasar Leuwiliang pada tahun 2016 sekitar 98,035 $\mathrm{m}^{3}$.Tempat pengomposan sebanyak 6 batch, masingmasing berukuran $14 \mathrm{~m} \times 13,5 \mathrm{~m} \times 1 \mathrm{~m}$ dengan satu batchnya terdiri dari 4 bak. Masingmasing bak berukuran $7 \mathrm{~m} \times 6,75 \mathrm{~m} \times 1 \mathrm{~m}$. Ukuran batch maupun bak berdasarkan jumlah sampah organik yang akan didaur ulang sebanyak $63,56 \mathrm{~m}^{3}$.

\subsection{Pengolahan Sampah Organik}

Sampah organik yang telah dipilah kemudian akan dimasukkan kedalam mesin pencacah, untuk digunakan sebagai bahan baku kompos. Mesin pencacah (Chopper) yang digunakan satu unit dengan kapasitas 500 kg/jam. Kemudian sampah organik telah dicacah, diangkut menuju bak pengomposan. Proses pengomposan menggunakan EM4 (Efektif Mikroorganisme) sebagai bioaktivator. Bahanbahan yang akan digunakan dalam proses pengomposan terdiri dari bahan sampah organik kering, bahan sampah organik basah, bioktivator dan bahan tambahan seperti dedak dan molase. Bioaktivator harus dicampur secara merata pada sampah organik yang akan dikomposkan. Proses pengadukan dibutuhkan pada proses ini agar suhu pada kompos berada pada suhu optimal yaitu 45$65^{\circ} \mathrm{C}$. Pengadukan akan dilakukan 3-4 hari sekali pada tiap-tiap bak.
Proses pengomposan membutuhkan waktu selama 3 minggu. Kompos yang telah matang akan diayak dengan menggunakan mesin pengayak kompos. Mesin pengayak yang digunakan di TPST yaitu sekitar 7 unit. Kompos hasil pengayakan akan dikemas dengan karung dan siap dipasarkan. Dari hasil pengomposan selama 21 hari dengan bahan baku kompos sebesar 3492,07 kg/hari dihasilkan kompos sebesar 1047,62 kg/hari (1 ton/hari) atau setara dengan 21 karung/hari.

\subsection{Pengelolaan Sampah Non Organik}

Pengelolaan sampah non organik dilakukan pemilahan, dan pengelempokan sesuai dengan jenisnya, plastik, karton, kertas, kain. Kayu, logam dan lain lain. Khusus untuk sampah plastik akan dilakukan pencucian terlebih dahulu sebelum di packing dan dijual.

Sampah plastik yang akan dijual ke pelapak sampah terdiri dari beberapa jenis plastik, jenis plastik tersebut adalah Polyethylene (PET) yaitu sampah botol plastik, Polypropylene (PP) yaitu sampah gelas plastik. Sedangkan sampah plastik yang tidak dapat dijual terdiri dari jenis plastik High Density Polyethylene (HDPE) yaitu sampah kantong kresek, Polystyrene (PS) yaitu stereofoam dan Polypropylene (PP) yaitu kemasan plastik. 
Potensi Pemanfatan Sampah di Pasar Leuwiliang, Cigudeg dan Jasinga Kabupaten Bogor melalui Pengolahan Sampah Terpadu

Sampah non organik yang tidak dapat dijual seperti sampah potongan kertas koran, kantong kresek, kemasan plastik, bahan berbahaya dan beracun seperti karbit dan korek api gas, stereofoam, potongan kerdus, potongan karung, tissue bekas dan keranjang ayam yang merupakan residu sampah akan diangkut ke TPA Galuga Bogor. Tetapi untuk sampah B3 seperti karbit dan korek api gas akan diberikan kepada pihak pengelola sampah B3 oleh pihak TPA Galuga Bogor. Oleh karena itu pihak pasar membawa seluruh residu termasuk sampah B3 ke TPA Galuga Bogor.

\subsection{Residu Sampah}

Dari hasil proyeksi timbulan sampah pada tahun 2016-2026 dapat dilihat bahwa potensi sampah yang dapat dimanfaatkan kembali baik menjadi pupuk organik (dari sampah organik) maupun langsung dijual (sampah non organik) adalah 88,94\%-99,44\% sehingga residu yang akan dibuang ke TPA Galuga Bogor adalah sebesar 24,86 $\mathrm{m}^{3}-1,52 \mathrm{~m}^{3}$. Sedangkan sampah yang akan masuk ke TPST Pasar Leuwiliang (seluas $826 \mathrm{~m}^{2}$ ) sebesar 199,88 $\mathrm{m}^{3}-269,66 \mathrm{~m}^{3}$ dengan kebutuhan lahan TPST seluas $777,37 \mathrm{~m}^{2}$, sehingga dapat disimpulkan bahwa lahan tersedia dapat menampung total timbulan sampah dari Pasar Leuwiliang, Pasar Cigudeg dan Pasar Jasinga hingga tahun 2026 mendatang.
Proyeksi residu sampah masing-masing pasar dapat dilihat pada Tabel 4 hingga Tabel 6.

Tabel 4

Proyeksi Residu Sampah Pasar Leuwiliang

\begin{tabular}{|c|c|c|c|c|c|}
\hline N0 & TAHUN & $\begin{array}{c}\text { TIMBULAN } \\
\text { SAMPAH }\left(\mathrm{m}^{3}\right)\end{array}$ & $\begin{array}{c}\text { PERSENTASE } \\
\text { PENYISIHAN (\%) }\end{array}$ & $\begin{array}{c}\text { REDUKSI } \\
\text { SAMPAH }\left(\mathrm{m}^{3}\right)\end{array}$ & $\begin{array}{c}\text { RESIDU } \\
\text { SAMPAH }\left(\mathrm{m}^{3}\right)\end{array}$ \\
\hline 1 & 2016 & 46.36 & 89.67 & 41.57 & 4.79 \\
\hline 2 & 2017 & 47.29 & 90.67 & 42.88 & 4.41 \\
\hline 3 & 2018 & 48.24 & 91.67 & 44.22 & 4.02 \\
\hline 4 & 2019 & 49.21 & 92.67 & 45.60 & 3.61 \\
\hline 5 & 2020 & 50.19 & 93.67 & 47.01 & 3.18 \\
\hline 6 & 2021 & 51.19 & 94.67 & 48.46 & 2.73 \\
\hline 7 & 2022 & 52.22 & 95.67 & 49.96 & 2.26 \\
\hline 8 & 2023 & 53.26 & 96.67 & 51.49 & 1.77 \\
\hline 9 & 2024 & 54.33 & 97.67 & 53.06 & 1.27 \\
\hline 10 & 2025 & 55.41 & 98.67 & 54.68 & 0.74 \\
\hline 11 & 2026 & 56.52 & 99.67 & 56.34 & 0.19 \\
\hline
\end{tabular}

Tabel 5

Proyeksi Residu Sampah Pasar Cigudeg

\begin{tabular}{|c|c|c|c|c|c|}
\hline NO & TAHUN & $\begin{array}{c}\text { TIMBULAN } \\
\text { SAMPAH }\left(\mathbf{m}^{\mathbf{3}}\right)\end{array}$ & $\begin{array}{c}\text { PERSENTASE } \\
\text { PENYISIHAN }(\%)\end{array}$ & $\begin{array}{c}\text { REDUKSI } \\
\text { SAMPAH }\left(\mathbf{m}^{3}\right)\end{array}$ & $\begin{array}{c}\text { RESIDU } \\
\text { SAMPAH }\left(\mathbf{m}^{\mathbf{3}}\right)\end{array}$ \\
\hline 1 & 2016 & 57.73 & 82.29 & 47.51 & 10.22 \\
\hline 2 & 2017 & 58.89 & 83.99 & 49.46 & 9.43 \\
\hline 3 & 2018 & 60.06 & 85.69 & 51.47 & 8.60 \\
\hline 4 & 2019 & 61.27 & 87.39 & 53.54 & 7.73 \\
\hline 5 & 2020 & 62.49 & 89.09 & 55.67 & 6.82 \\
\hline 6 & 2021 & 63.74 & 90.79 & 57.87 & 5.87 \\
\hline 7 & 2022 & 65.02 & 92.49 & 60.13 & 4.88 \\
\hline 8 & 2023 & 66.32 & 94.19 & 62.46 & 3.85 \\
\hline 9 & 2024 & 67.64 & 95.89 & 64.86 & 2.78 \\
\hline 10 & 2025 & 68.99 & 97.59 & 67.33 & 1.66 \\
\hline 11 & 2026 & 70.37 & 99.29 & 69.87 & 0.50 \\
\hline
\end{tabular}

Tabel 6

Proyeksi Residu Sampah Pasar Jasinga

\begin{tabular}{|c|c|c|c|c|c|}
\hline No & TAHUN & $\begin{array}{c}\text { TIMBULAN } \\
\text { SAMPAH }\left(\mathrm{m}^{\mathbf{3}}\right)\end{array}$ & $\begin{array}{c}\text { PERSENTASE } \\
\text { PENYISIHAN (\%) }\end{array}$ & $\begin{array}{c}\text { REDUKSI } \\
\text { SAMPAH }\left(\mathrm{m}^{\mathbf{3}}\right)\end{array}$ & $\begin{array}{c}\text { RESIDU } \\
\text { SAMPAH }\left(\mathrm{m}^{\mathbf{3}}\right)\end{array}$ \\
\hline 1 & 2016 & 120.65 & 94.87 & 114.46 & 6.19 \\
\hline 2 & 2017 & 123.15 & 95.37 & 117.45 & 5.70 \\
\hline 3 & 2018 & 125.62 & 95.87 & 120.43 & 5.19 \\
\hline 4 & 2019 & 128.13 & 96.37 & 123.48 & 4.65 \\
\hline 5 & 2020 & 130.69 & 96.87 & 126.60 & 4.09 \\
\hline 6 & 2021 & 133.30 & 97.37 & 129.80 & 3.51 \\
\hline 7 & 2022 & 135.97 & 97.87 & 133.07 & 2.90 \\
\hline 8 & 2023 & 138.69 & 98.37 & 136.43 & 2.26 \\
\hline 9 & 2024 & 141.46 & 98.87 & 139.87 & 1.60 \\
\hline 10 & 2025 & 144.29 & 99.37 & 143.38 & 0.91 \\
\hline
\end{tabular}




\section{KESIMPULAN}

1. Pola pengumpulan sampah kondisi eksisting Pasar Leuwiliang, Pasar Cigudeg dan Pasar Jasinga masih belum optimal dan dapat ditingkatkan dengan memanfaatkan kembali sampah yang masih bisa diolah.

2. Sebanyak 62\% masyarakat Pasar Leuwiliang, $71 \%$ masyarakat Pasar Cigudeg dan 84\% masyarakat Pasar Jasinga bersedia melakukan pemilahan sampah dari sumbernya, oleh karena itu pemilahan sampah direncanakan akan dilakukan dari sumber sampah.

3. Potensi sampah tahun 2016-2026 yang bisa dimanfaatkan kembali, baik menjadi pupuk organic (sampah organik), ataupun langsung dijual (sampah non organik), adalah dari Pasar Leuwiliang 89,67\%99,67\%, dari pasar Cigudeg 57,73\%-70\% dan pasar Jasinga adalah 94,87\%- 99,37\%

4. Alternatif terpilin dalam Perencanaan Teknis Operasional untuk pewadahan yaitu alternatif pewadahan 3, sedangkan untuk pengangkutan yaitu alternatif 2 .

5. Pewadahan berupa tong/drum sampah plastik, alat pengumpul berupa gerobak dan alat angkut berupa dump truck akan dipisah antara yang organik dengan non organik.
6. Luas lahan Tempat Pengolahan Sampah Terpadu (TPST) yang akan direncanakan seluas $\pm 826 \mathrm{~m}^{2}$ dan luas TPST itu sendiri seluas $777,37 \mathrm{~m}^{2}$ dengan kapasitas sebesar $412,475 \mathrm{~m}^{3}$.

7. Total kompos yang dihasilkan berdasarkan perhitungan adalah sebesar 1047,62 $\mathrm{kg} /$ hari atau sekitar 21 karung kompos dan total sampah non organik yang akan dijual ke pemasok sampah non organik adalah sebesar 708,95 kg.

\section{DAFTAR PUSTAKA}

[1] Dinas Kebersihan dan Pertamanan Kabupaten Bogor,

[2] Matsui, Y, Trang, D.T.T., Thanh, N. P. Estimation of Waste Generation and Recycling Potential from Traditional Market: A Case Study in Hue City, Vietnam. Journal of Environmental Protection, 2015, 6, hal. 308-320. http://dx.doi.org/10.4236/jep.2015.64031

[3] Hartono, D.M., Kristanto, G.A., Amin, S. Potential Reduction of Solid Waste Generated from Traditional and Modern Markets, International Journal of Technology, 2015, Vol. 6 (5), hal. 838846

[4] Undang-Undang Nomor 18 Tahun 2008 tentang Pengelolaan Sampah 